\title{
ANGULAR KINEMATICS OF THE GAIT OF CHILDREN WITH DOWN'S SYNDROME AFTER INTERVENTION WITH HIPPOTHERAPY
}

\author{
Copetti $\mathrm{F}^{1}$, Mota $\mathrm{CB}^{2}$, Graup $\mathrm{S}^{2}$, Menezes $\mathrm{KM}^{3}$ \& Venturini EB ${ }^{3}$ \\ ${ }^{1}$ Human Movement Education and Research Laboratory, Department of Sports Methods and Techniques, Physical \\ Education and Sports Center, Universidade Federal de Santa Maria - UFSM, Santa Maria, RS - Brazil \\ ${ }^{2}$ Graduate Physical Education Program, Universidade Federal de Santa Catarina, Florianópolis, SC - Brazil \\ ${ }^{3}$ Equine Therapy Project, UFSM \\ Correspondence to: Fernando Copetti, Centro de Educação Física e Desportos, Universidade Federal de Santa Maria, \\ Fxa. de Camobi, Km 09, Cidade Universitária, CEP 97105-900, Santa Maria, RS - Brasil, \\ e-mail: copettif@gmail.com
}

Received: 08/01/2007 - Revised: 12/06/2007 - Accepted: 30/07/2007

\begin{abstract}
Objective: To investigate the effect of a program of horseback riding therapy on the angular kinematics of the ankle and knee in children with Down's syndrome. Method: The study group was composed of three male children with a mean age of 7.3 years ( \pm 2.08$)$. The analyses were done individually and the post-test was performed after thirteen treatment sessions. The duration of each horseback riding therapy session was fifty minutes, and the interval between sessions was seven days. The gait analysis was carried out using the Peak Motus ${ }^{\mathrm{TM}}$ system. Results: Statistical differences in ankle joint were observed for all subjects. For knee joint, differences were found at different moments of the cycle, without presenting any observable trend. Conclusion: Horseback riding therapy produced positive changes in the angular behavior of the ankle and little effect on the knee.
\end{abstract}

Key words: Gait; Down's syndrome; horseback riding therapy.

\section{RESUMO}

\section{Comportamento angular do andar de crianças com síndrome de Down após intervenção com Equoterapia}

Objetivo: Verificar o efeito de um programa de equoterapia no comportamento angular do tornozelo e joelho de crianças com síndrome de Down (SD). Método: Fizeram parte do estudo três crianças do sexo masculino com média de idade de 7,3 anos $( \pm 2,08)$. As análises foram realizadas intra-sujeitos, sendo o pós-teste realizado após treze sessões de tratamento. As intervenções com equoterapia tiveram duração de cinqüenta minutos, com intervalos de sete dias. A análise do andar foi realizado pelo Sistema Peak Motus ${ }^{\mathrm{TM}}$. Resultados: Observaram-se alterações significativas para a articulação do tornozelo para todos os sujeitos. Para a articulação do joelho, diferenças foram verificadas em momentos distintos do ciclo, não apresentando uma tendência observável. Conclusão: A equoterapia promoveu alterações positivas no comportamento angular da articulação do tornozelo, com pouco efeito sobre o joelho.

Palavras-chave: andar; síndrome de Down; equoterapia. 


\section{INTRODUCTION}

The use of equestrian activities as a therapeutic resource has increased considerably in the last decades. Hippotherapy or Equine therapy, as it is called in Brazil, uses the horse as an agent that promotes physical, psychological and educational gains ${ }^{1}$. Although it is not a new practice, scientific interest is recent and still lacks research. In addition to that, studies dedicated to this area of knowledge do not always confirm the reported qualitative analyses ${ }^{2}$, which indicates a discrepancy between the statistical data obtained and the positive results observed by therapists, relatives and health professionals. Studies have shown improvement in gross motor functions after intervention with hippotherapy, especially in gait, running and jumping performance of cerebral palsy sufferers ${ }^{3,4}$, in the symmetry of muscular activity of the torso ${ }^{5}$ and in four-point kneeling and stance balance ${ }^{6}$, as well as psychological and social benefits.

In the last few years, people with different pathologies have used hippotherapy, amongst whom Down syndrome (DS) individuals was one of the groups which most sought this treatment at the Universidade Federal de Santa Maria. This syndrome usually generates in the child a hypotonic state and a gait characterized by a wide support base with feet pointed outward and stiff knees rotated externally, therefore increasing support stability by compensating current knee stability (semiflexion or hyperextension $)^{7}$. The slower cadence and the anterior pelvic tilt, which characterize of this syndrome, produce an atypical tiptoe gait ${ }^{8}$, while deficits in the postural control system may be partially responsible for balance problems in these children ${ }^{9}$. However, the DS child can slowly reach mature levels of movement when stimulated ${ }^{10}$. In that case, considering the therapeutic potential produced by the wealth of stimuli generated by the horse's movement ${ }^{3,4}$ and the common traits of the DS child's gait, the purpose of this study was to verify the effect of equine therapy on the angular movement of the knee and ankle of DS children with known alterations in the ankle angle curve during gait.

\section{MATERIALS AND METHODS}

The present study investigated three DS male children, with mean age of 7.3 years $( \pm 2.08)$. Initially, eight children enrolled in the hippotherapy project at the Universidade Federal de Santa Maria in the year 2005. Those who displayed instability in the atlanto-axial ${ }^{11}$ region were excluded (1), as well as those with no alteration in ankle angle values during gait (1), those participating in another type of therapy (2) and those who did not complete the anticipated number of sessions (1).
The individuals' parents signed the written informed consent. The intervention protocols were approved by the Ethics in Research Committee of the Health Sciences Center of Universidade Federal de Santa Maria and follow the regulations of Resolution 196/96 of the National Health Council on research involving human beings, according to CEPE/CCS/UFSM Approval 034/2005.

The collection of ankle and knee angular movement during pre- and post-treatment gait was conducted in the laboratory using the Peak Motus ${ }^{\mathrm{TM}}$ movement analysis system. Ten attempts were made for each side of the body, with gait velocity selected by the individual, and the five best performances of each hemibody were considered for analysis. Two-dimensional footage was taken using a camera with $60 \mathrm{~Hz}$ image acquisition. The children were barefoot and wore bathing suits to allow the attachment of reflexive markers positioned on the anatomical points of the tuberosity of the greater trochanter, the lateral condyle of the tibia, the lateral malleolus, the second metatarsal head and the top of the heel bone. The angles of the pelvis and the hip could not be evaluated because the anatomical points that define them were covered by the arm's natural movement, which is very limited in these individuals, making digitalization impossible during some percentiles of the cycle. The ankle angle was defined as the angle between the perpendicular to the line of the leg and the foot (positive for dorsiflexion), and the knee angle as the angle between the extension of the line of the thigh and the leg (positive for flexion). These angles during gait were analyzed between subjects. As parameters of normality, we used the angle curves $^{12}$ which are generally considered normal from the age of five.

Literature does not specify a period for intervention with hippotherapy, but alterations are reported as early as twelve ${ }^{13,14}$ sessions. Therefore, we adopted an intervention period of thirteen sessions, each session lasting fifty minutes including the time of approach, mounting and closing, with a seven-day interval between sessions. Mounting time with the horse moving was always greater than 35 minutes. Activities were designed to stimulate different tone adjustments, considering that hypotonia is a characteristic of DS. Activities followed a basic Education/Reeducation ${ }^{1}$ program and were held in an area containing great diversity of environmental stimuli and appropriate for holding these activities. They provided variations in horse movement (walk and trot), pavement (sand, asphalt and grass), direction and movement combinations. The horse-riding equipments were the saddle cloth and girth with strap suited for this practice, protection helmet and extremely docile and trained animals. The continuous use of the feet on the stirrups was mandatory and controlled. 
Data analysis was performed using the Statistical Software Package SPSS 11.5 for Windows. The Student $t$-test for independent samples was used to analyze the difference between hemibodies. As no differences were observed, the average of both hemibodies was used for further analysis. The Student $t$-test was used for dependent samples in order to verify differences between pre-test and post-tests. We compared values at every $10 \%$ of the gait cycle and adopted a level of significance of 0.05 . The variables showed normal distribution and were evaluated using the Shapiro-Wilk test.

\section{RESULTS AND DISCUSSION}

The analysis of angle values, during the gait cycles, allowed the demonstration of the angular movement of each individual before and after hippotherapy. During single support, the ankle angle curve for subject I (Figure 1) indicates lack of control over dorsiflexor muscle action when the body passes over the support foot. During the entire cycle, the post-equine therapy curve was very similar to the reference curve, indicating a positive change in movement. The knee angle graph for subject I (Figure 2) shows values closer to those described in literature as normal values, with significant differences in the beginning of the cycle, when the heel leaves the ground and at the moment of maximum flexion, respectively.

The values presented by subject II show that the ankle movement (Figure 3 ) is very similar to the one

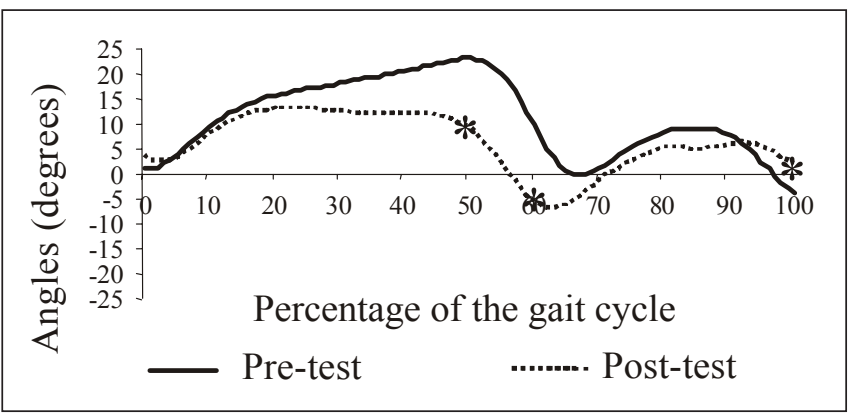

Figure 1.Ankle angular movement before and after Hippotherapy (subject I) $\left({ }^{*} \mathrm{p}<0.05\right)$.

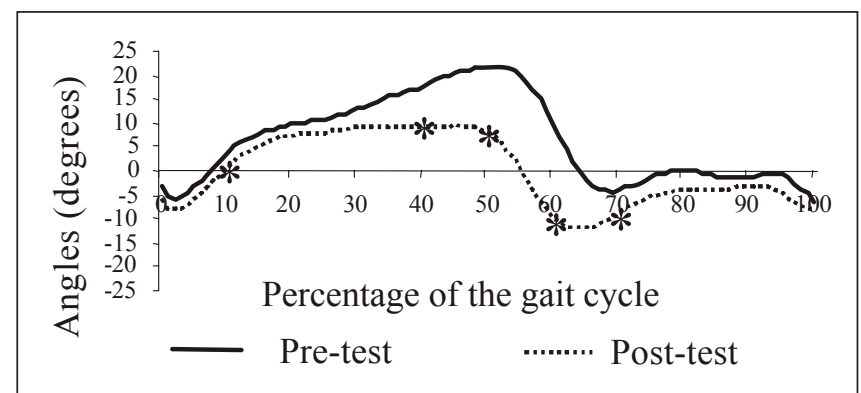

Figure 3. Ankle angular movement before and after Hippotherapy (subject II) $(* \mathrm{p}<0.05)$. presented by subject I, earning the same considerations. In the knee angular movement (Figure 4), at the end of the first flexion wave, when the femoral biceps is activated to make a rapid extension, the angle values increased, meaning that the subject executes the gait with slightly bent knees. The same occurs at the end of the final balance phase, when the heel touches the ground.

For subject III, both before and after equine therapy, the ankle curve (Figure 5) indicates that the first contact of the foot with the ground does not occur with the heel, characterizing therefore an insufficient dorsiflexion at the moment of contact. During single support, the post-equine therapy curve appears to be similar to the reference curve, showing a satisfactory action of the dorsiflexor muscles to free the foot. The significant differences were observed, for both sides, moments before the feet leave the ground. The values corresponding to the pre-test knee angular movement for subject III (Figure 6) are lower than the ones observed after the treatment, showing an increase in the flexion of the knee during the cycle.

Upon analysis of the ankle and knee angular movement after intervention, a significant difference was observed in the ankle, predominantly in the balance phase and the progression of the initial touch of the foot for all subjects, which was also observed in a similar study ${ }^{13}$, showing the increase in plantar dorsiflexion in this phase. During single support, the pre-test curves of subjects I and II indicated a lack of control over dorsiflexor muscle action when the body passes over the support foot. It

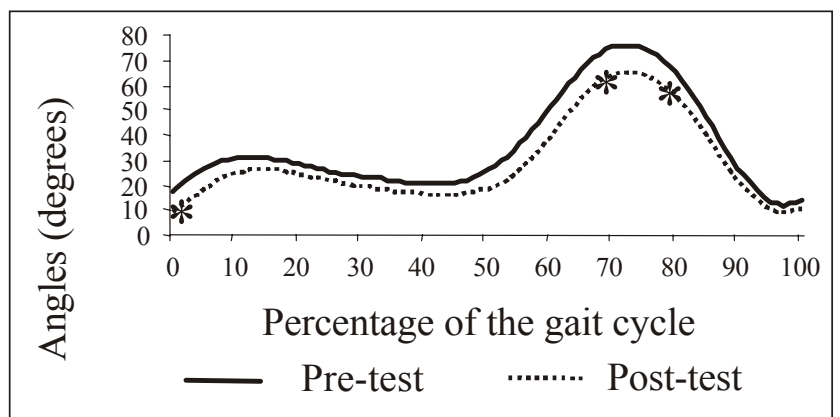

Figure 2. Knee angular movement before and after Hippotherapy (subject I) $\left({ }^{*} \mathrm{p}<0.05\right)$.

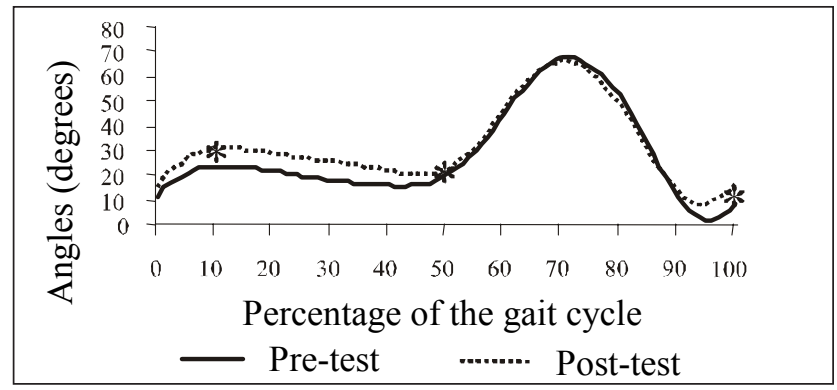

Figure 4. Knee angular movement before and after Hippotherapy (subject II) $(* \mathrm{p}<0.05)$. 


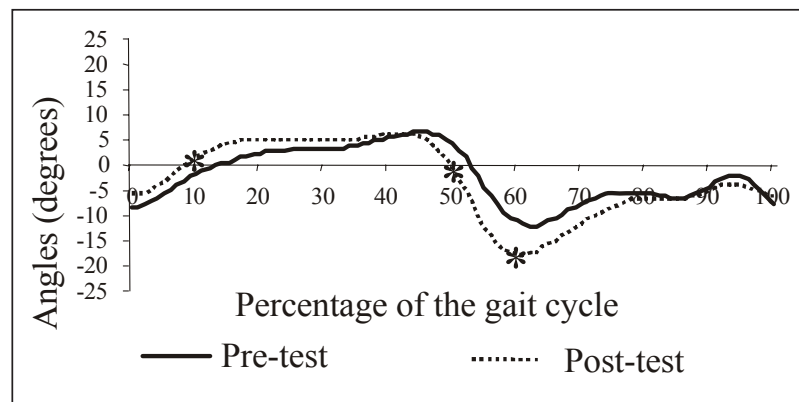

Figure 5. Ankle angular movement before and after Hippotherapy (subject III) $(* \mathrm{p}<0.05)$.

is important to take into account that single support is the most unstable period of the cycle, since the body is imbalanced while the center of gravity is accelerated forward and the center of pressure is under the foot ${ }^{12,15}$. While the sole of the foot is in contact with the ground, the dorsiflexion of the ankle is resisted by the plantar flexors that perform the transfer of the tibia and fibula over the talus bone, acting excentrically ${ }^{16}$. The greater the joint instability, the earlier DS individuals activate the antagonist muscles ${ }^{17}$.

For the knee joint, statistically significant differences were verified at different points of the cycle and did not represent an observable trend. The angle values of the knee joint shown by subjects II and III in the pre-test were lower than those shown after the treatment. The quadriceps acts from the flexion to the extension of the leg, providing stability to the knee in the beginning of the support phase ${ }^{18}$. The mounting position allows a variety of stimuli that develop balance reactions, improvement in posture, trunk control and normalization of muscle tone $\mathrm{e}^{3,19}$. Therefore, this variation in movement may be caused by the strengthening of the dorsiflexor muscles as a result of the foot's position on the stirrup during the sessions, which helps its dorsiflexion and eversion.

The benefits of activities with horses are attributed to the movement produced by the animals' step which deliver a combination of sensorial stimuli to the basic human systems triggering amplified motor and sensory integration ${ }^{3,4,20}$. These activities promote greater motor control, allowing increase in muscle tone, and the repetition of the movement promotes the reeducation of postural reflexes, balance reactions and space-time perception of several body segments ${ }^{19}$ which, in addition to muscle strengthening, would explain the observed alterations. However, it should be noted that the effect of equine therapy involves a set of combinations and adjustments which contribute to the practitioner's condition in general.

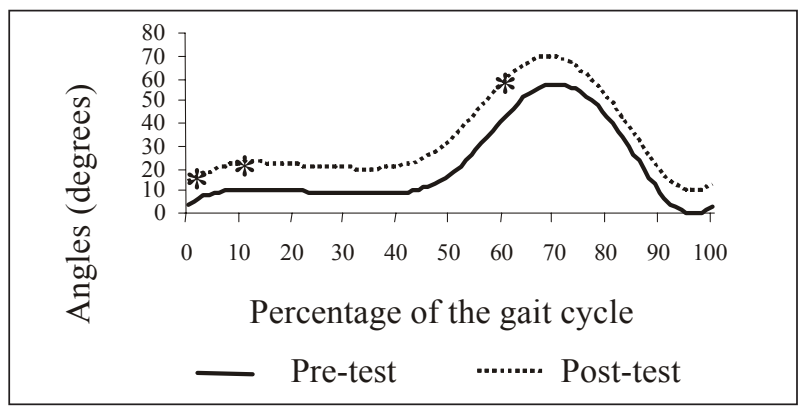

Figure 6. Knee angular movement before and after Hippotherapy (subject III) $(* \mathrm{p}<0.05)$.

This study has some limitations, such as the number of investigated subjects and the control of daily activities, among other things. However, the findings allow the conclusion that, for this group, the motor stimulation activities of the hippotherapy sessions provided considerable modifications in the knee and ankle angle variables. Such modifications were observed in the quality of gait, with more efficiency in ankle movement and with little effect on the knee. This suggests that the activities performed in equine therapy can generate a combination of favorable stimuli for better movement control, promoting a greater approximation of the DS child's gait to the standard of normality described in literature.

\section{REFERENCES}

1. Associação Brasileira de Equoterapia [homepage na Internet]. Brasília: ANDE-Brasil; [atualizado em 2006 Set 27; acesso em 09 Nov 2006] Disponível em: http://www.equoterapia.org.br/ equoterapia.php.

2. Pauw J. Therapeutic horseback riding studies: problems experienced by researchers. Physiotherapy. 2000;86:523-7.

3. Sterba JA, Rogers BT, France AP, Vokes DA. Horseback riding in children with cerebral palsy: effect on gross motor function. Dev Med Child Neurol. 2002;44:301-8.

4. Cherng R, Liao H, Leung HWC, Hwang A. The effectiveness of therapeutic horseback riding in children with spastic cerebral palsy. Adapt Phys Activ Q. 2004;21(2):103-21.

5. Benda W, Mcgibbon NH, Grant K. Improvements in muscle symetry in children with cerebral palsy after equine-asssisted therapy (hippotherapy). J Altern Complement Med. 2003; 9(6):817-25.

6. Blery MJ, Kauffman N. The effects of therapeutic horseback riding on balance. Adapt Phys Activ Q. 1989;6:221-9.

7. Palisano RJ, Walter SD, Russel DJ, Rosenbaum PL, Gémus M, Galuppi B, et al. Gross motor function of children with Down syndrome: creation of motor growth curves. Arch Phys Med Rehabil. 2001;82:494-500.

8. Kim B, Bang DY, Kim B. Gait characteristics in Down's syndrome. Gait Posture. 1995;3(2):84. 
9. Shumway-Cook A, Woolacott M. Dynamics of postural control in the child with Down syndrome. Phys Ther. 1985;65(9): 1315-22.

10. Tolocka RE. Estabilidade motora de pessoas portadoras de síndrome de Down, em tarefa de desenhar [tese]. Campinas: UNICAMP; 2000.

11. Barros TEP, Oliveira RP, Rodrigues NR, Galvão PEC, Souza MPE. Instabilidade atlanto-axial na síndrome de Down. Rev Bras Ortop. 1998;2(33):91-4.

12. Sutherland DH, Kaufman KR, Moitoza JR. Cinemática da marcha humana normal. In: Rose J, Gamble JG, editores. Marcha humana. $2^{a}$ ed. São Paulo: Premier; 1998. p. 23-45.

13. Graup S, Oliveira RM, Link DM, Copetti F, Mota CB. Efeito da Equoterapia sobre o padrão motor da marcha em crianças com síndrome de Down: uma análise biomecânica. Efdeportes Revista Digital [periódico na Internet]. 2006 Maio [acesso em 06 Jun 2006]; 96(11): [aproximadamente 10 p.]. Disponível em: http://www.efdeportes.com/efd96/equot.htm.

14. Casady RL, Nichols-Larsen DS. The effect of hippotherapy on ten children with cerebral palsy. Pediatr Phys Ther. 2004;16(3): $165-72$.
15. Wicart P, Maton B. Body equilibrium at the end of gait initiation: importance of ankle muscular force as evidenced in clubfoot children. Neurosci Lett. 2003;351:67-70.

16. Costa H, Glitsch U, Baumann W, Amadio AC. Momentos articulares resultantes durante o andar e o correr de crianças. Rev Bras Biomec. 2001;3:7-14.

17. Almeida GL. Biomecânica e controle motor aplicado no estudo de disfunções motoras. Motriz. 1999;5(1):178-82.

18. Inman VT, Ralston HJ, Tood F. A locomoção humana. In: Rose J, Gamble JG. Marcha humana. 2a ed. São Paulo: Premier; 1998. p. 1-21.

19. Kuczynskim M, Slonka K. Influence of artificial saddle riding on postural stability in children with cerebral palsy. Gait Posture. 1999;10:154-60.

20. Krapivkin A, Nedashkovsky O, Khavkin A, Terent'eva I, Kolesnik L. Effect of intensive course of hipotherapy at children with cerebral palsy. Brain Dev. 2001;23:189. 